FINAL

\title{
Greece's Ulrike Meinhof: Pola Roupa and the Revolutionary Struggle
}

CONTACT George Kassimeris g.kassimeris@wlv.ac.uk Professor in Security Studies, FoSS, University of Wolverhampton, UK, WV1 1SB, West Midlands, UK.

\begin{abstract}
Pola Roupa's arrest in 2016 was the final nail in the coffin of Revolutionary Struggle, the first guerrilla group to emerge on Greece's terrorist landscape after the 2002 collapse of 17 November, the country's premier terrorist organisation for almost three decades and one of Europe's longest-running terror gangs. Drawing on the judicial investigation findings, courtroom testimonies, RS communiqués and interviews with counter-terrorism officials, this article tells the story of Pola Roupa, the first female leader of a Greek terrorist group in an attempt to understand the political reasons and motivational factors that led to her involvement in terrorism. At the same time, the article hopefully contributes to the study and understanding of women and terrorism by providing an insight into the role and experience of a female militant inside Greece's gender-conservative and overwhelmingly male-dominated armed struggle movement.
\end{abstract}

On 21 February 2016 Pola Roupa, Greece's most-wanted terrorist and leader of the Revolutionary Struggle (RS) group, stunned the country by hijacking a helicopter in order to free her partner and fellow RS militant, Nikos Maziotis, held in the maximum-security prison of Korydallos in Athens. In a daring, one-woman commando-style operation, Roupa took the helicopter pilot hostage, forcing him at gunpoint to fly over the prison courtyard. The attempted jailbreak, however, failed when the pilot resisted, managing in the struggle that ensued to regain control and land the helicopter away from Korydallos. Roupa ran off but 
was eventually arrested a year later by Greek counter-terrorism police in a middle-class suburb south-east of Athens, where she was living under an assumed identity with her 6-yearold son.

Roupa's arrest was the final nail in the coffin of RS, marking the end of a 15-year campaign of politically motivated violence by the first guerrilla group to emerge on the country's terrorist landscape after the 2002 collapse of $17 \mathrm{~N}$, Greece's premier terrorist organisation and one of Europe's longest-running terror gangs ${ }^{1}$. Led by Maziotis and Roupa Revolutionary Struggle picked up the baton of terrorist revolutionary violence in 2003 , before even the $17 \mathrm{~N}$ trial had come to an end and sentences were passed. The demise of $17 \mathrm{~N}$ rather than dealing a fatal blow to the country's armed struggle movement, diminishing the attractiveness of political violence as a strategic tool, led instead to an upsurge in and intensification of revolutionary violence. In 2008, RS was joined by an anarchist-oriented guerrilla group, the Conspiracy of Cells of Fire (CCF) and they went on to become the most active of Greece's post-17N generation of urban guerrilla groups. ${ }^{2}$

This new generation of Greek militants, when compared to their predecessors, differ little in how they conduct their violent campaigns. At the same time, however, the parallel emergence and evolution of RS and CCF, two ideologically diverse political factions from the extraparliamentary left and anarchist movements, which had to modify their ideas and political rationales in order to promote and justify violence, demonstrates how confusing and unpredictable Greece's terrorist landscape remains. With regards to their profiles, membership and operational behaviour, although hierarchical attitudes, age subordinations and gender stereotypes continue to exist, they have become less visible. ${ }^{3}$ During the $17 \mathrm{~N}$ years, for example, Pola Roupa as a female Greek militant would have not been able to 
transgress the norms of typical female behaviour. Her gender and young age would have consigned her to a peripheral role inside the organisation, if not to a total exclusion.

Historically, the European experience shows that women have long been involved in politically motivated violence but very few have achieved leadership positions within these organisations. With very few exceptions militant women like Adriana Faranda in the Italian Red Brigades and Ulrike Meinhof in the German Baader-Meinhof Gang who held crucial leadership positions in the 1970s, the development of group ideology, strategic leadership and motivation has generally been seen as the concern, if not the monopoly, of men.

Greece, a country with a persistently rich tradition in politically motivated violence, constitutes no exception. At the time of writing, Pola Roupa remains the first and only female leader of a Greek terrorist group. Drawing on the judicial investigation findings, courtroom testimonies, RS communiqués and interviews with counter-terrorism officials, this article attempts to tell the story of Pola Roupa inside the RS in an attempt to understand the political reasons and motivational factors that led to her involvement in terrorism. At the same time, the article hopefully adds to the study and understanding of female political violence by providing an insight into the role and experience of a female militant inside Greece's gender-conservative and overwhelmingly male-dominated armed struggle movement.

\section{Militants in Love: Pola Roupa meets Nikos Maziotis}

Pola Roupa was born in 1969 in the Greek town of Kalamata, a bustling seaside location in the beautiful Peloponnese region, full of whitewashed buildings with terracotta roof tops, narrow cobbled streets and tavernas serving traditional foods. Her intellectuality was nurtured in childhood by her well-read Marxist father whose participation in the Greek resistance seems to have had a strong formative influence on Roupa's politicisation and her 
subsequent involvement in radical student politics, when she read Mathematics at Athens University, attests to that. Roupa's political radicalisation came in 1991 when she was arrested and detained by the police for fly-posting. Describing her arrest and treatment at the hands of the Greek police, Roupa said that she 'felt on my skin the full force of the Greek state's cruelty and barbarity. It was then, when I fully realised for the first time that we have a war against the state'. ${ }^{4}$

The watershed moment in Roupa's life came four years later in November 1995 when she, as part of a group of 500 militants, took part in the occupation of the Athens Polytechnic to mark the anniversary of the 1973 student uprising that was brutally crushed by the Greek junta when it used tanks to crash a student-worker occupation. It was then that Roupa first met Nikos Maziotis and Lambros Foundas and soon after they formed the Revolutionary Struggle, plunging into the conspiratorial underground of Greece's armed struggle movement.

Roupa's love for Maziotis and her admiration for his revolutionary fervour and utopian aspirations meant that she would follow him selflessly ever since. Maziotis, the youngest of five siblings was 'low-key and academically very strong at school' according to one of his older brothers, a priest with the Church of Greece. Maziotis's political awakening came in 1985 when a 15-year-old schoolboy Michalis Kaltezas was shot dead by a stray police bullet during a march to the American Embassy in Athens to mark the anniversary of the November 1973 Polytechnic student revolt. The Kaltezas incident had a profound influence on Maziotis who was the same age at the time. Twenty-four years later in December 2009 when a similar incident took place involving the shooting of another 15-year-old student Alexis Grigoropoulos by a police officer, Maziotis's RS retaliated by attacking a MAT riot police bus and a three-member strong police unit on foot patrol, leaving a policeman in critical condition. RS's reaction to the Grigoropoulos incident was effectively a copy of $17 \mathrm{~N}$ 's 
reaction to the Kaltezas death when the group detonated a remote-controlled bomb against a Greek MAT police bus fatally injuring one and wounding another fourteen.

Maziotis believed in the redemptive effect and practical use of violence. In 1999, he was given a 3-and-a-half year prison sentence for planting a bomb -which failed to explode outside the Development Ministry building back in December 1997 in protest against the installation of a gold metallurgy by multinational company in the village of Strymonikos, in Halkidiki, northern Greece. Throughout the trial, Maziotis refused to accept the charges and robustly defended his choices ideologically by insisting on having nothing to apologize for because he did not consider himself 'a criminal'. 'I am a revolutionary', he told the court, 'and for that I have nothing to repent. The only I regret I have is that the technical error prevented the bomb from exploding, so my fingerprint was found on it and I ended up here. That is the only thing I regret'.

Commitment to ideology as a guide for political action pervaded Maziotis' 1999 court testimony. Advocating social revolution 'by any means necessary', he argued that it was generally 'proven in Greek but also in international social and political history that no changes ever came about, and never did humanity achieve any progress - progress as I see it - through begging, through praying or by words alone' ${ }^{6}$ With absolute conviction of rightness, Maziotis argued that placing the bomb was not 'an act of terrorism but an act of revolutionary solidarity ${ }^{7}$. He also took issue with the notion introduced by the mainstream media that such violence was terrorism. The real terrorists, according to Maziotis, were not 'the revolutionaries and the militants' but 'the states themselves' ${ }^{8}$ Prison was seen by Maziotis's an alternative battleground to continue the struggle. His imprisonment led, in fact, to the consolidation of the group's collective identity and cemented the determination of its members to establish credibility as a revolutionary group by launching a campaign of violence. In many ways, 17N's sudden and unexpected collapse in 2002 precipitated RS's 
emergence, presenting Maziotis and Roupa with a unique opportunity to put themselves and their new group on the map and act upon their revolutionary beliefs. RS's debut attack on the Athens Evelpidon courthouse in September 2003, timed to coincide with the on-going 17N trial, was designed to send a clear message of intent as two bombs exploded fifteen minutes apart with no advance notice, severely wounding a policeman.

\section{Standing alongside $17 \mathrm{~N}$}

RS central ambition was to stand alongside $17 \mathrm{~N}$ in the Greek pantheon of great revolutionary forces. Convinced that 17N's revolutionary experiment could only be surpassed by a new revolutionary experiment, RS's principal objective was to 'shape a genuine revolutionary

current, equal to the requirements of the age'. ${ }^{9}$ Like $17 \mathrm{~N}$ before them, $\mathrm{RS}$ offered an analysis of a Greek society that required violence if it were to be changed. The group, in fact, saw its violence as historically necessary and inevitable consequence of long-standing domestic socio-political conditions. In that sense, RS fully embraced 17N's conception of political violence as a legitimate and necessary form of expression for those humiliated and mistreated by the ruthless state structures and mechanisms of capitalist power.

From its debut attack, the group presented themselves and their violence in terms of political dissent, moral conviction and armed insurrection. Narrating its discourse through lengthy attack communiqués RS elaborated the presentation of political events and expanded the dimensions of their violent context in an attempt to exaggerate the anomalies of the existing system, deny its legitimacy and propose alternative models.

An examination of RS attack communiqués and political announcements shows the group's constant search for key issues that would justify its revolutionary activism and serve as the basis for winning public sympathy and moral support for its strategic priorities. RS texts, stylistically very similar to past $17 \mathrm{~N}$ communiqués, were generally long, defensive and at 
times bombastic, offering a running commentary on domestic and international developments. RS writers explored a number of themes from which the group drew inspiration and motivation for its campaign: 'the trial of $17 \mathrm{~N}$ ', 'corruption within the Greek political establishment', 'police brutality', 'capitalist exploitation', 'globalization', 'the USled war on terror', 'the Arab-Israeli conflict', 'US hegemonic plans in the Balkans' - to name a few. In an attempt to display intellectual depth and thus increase the group's respectability vis-à-vis their intended audiences, RS writers presented their arguments in a jargon-ridden style which blended Marxist scientific pretence with trenchant obloquy that did not necessarily strengthen nor advance their general arguments.

Operationally, the group modelled its module operandi on past $17 \mathrm{~N}$ attacks, incorporating high-profile assassination attempts, armed raids, car bombings and rocket attacks. From its debut bomb attack to the 2007 rocket attack against the US Embassy in Athens and to its final operation in 2014 (a car-bomb attack of the Bank of Greece headquarters) the group demonstrated an undiminished penchant for high-profile and prestige targets.

\section{The recapture of Nikos Maziotis}

The story of RS' violence was meant to have come to an end in April 2010 when both Roupa and Maziotis together with four other core RS members were captured. At the time of the arrests, the Public Order Ministry under Michalis Chrysohoidis (who was also in charge during the $17 \mathrm{~N}$ breakup) declared the group moribund as it could only, in their estimation, count on three, maximum four members still at liberty. However, in October 2012 Maziotis and Roupa, having served the maximum 18 months in pre-trial detention, violated their conditional release and went on the run. ${ }^{10}$

The recapture of Nikos Maziotis in July 2014 after an armed exchange with police officers in the central tourist district of Athens came at a time when RS was in the process of a full- 
blown operational comeback as the 10 April 2014 Bank of Greece car bomb attack in Athens demonstrated. The dawn blast caused extensive damage to the building, blowing out windows and spreading chunks of concrete and shards of glass hundreds of metres away, making central Athens on the eve of the German Chancellor's official visit look like a war zone. The attack, RS's first in more than four years, was a carbon-copy of the 2009 Athens Stock Exchange operation and was clearly designed to put the group back on the map.

Maziotis was seriously injured in an exchange of fire with police officers which also left a policeman and two bystanders hurt. Despite wearing a wig and glasses, Maziotis had been spotted by an off-duty counter-terrorism officer and was followed and then stopped outside an outdoor equipment shop. When police officers ordered him to show his ID, Maziotis panicked and fired his pistol and then fled the scene on foot through the packed with tourists streets pursued by motorcycle-riding police officers. After a 10-minute frantic chase in a crowded tourist area, Maziotis was finally cornered and during another exchange of fire was apprehended after being hit in the shoulder by a police bullet. Before he was immobilized, a wounded Maziotis tried to commandeer a taxi that was caught in the standoff but the militant staggered and fell. By the time, counter-terrorism officers located the hideout of the RS couple, a fifth-floor apartment near the electric railway station in Maroussi, north of Athens, Roupa and their 4-year-old son had fled the area. According to a high-ranking counterterrorism official who spoke to the author on condition of anonymity the day after the incident: 'it was Maziotis's sheer arrogance and invincibility syndrome that led him to visit central Athens on a day that it was widely known that the police were to launch an operation to remove illegal immigrants and street vendors'. ${ }^{11}$

'Provoking a response from the state is a given'. 
Could the RS regroup and make a comeback under Roupa's sole leadership? With Maziotis behind bars once again, the group faced a terminal logistical and operational crisis. As a highlevel counter-terrorism official put it at the time: 'Roupa may be the group's chief ideologue talking the revolutionary talk as evidenced from her regular posts but it was Maziotis who walked the guerrilla walk. Without him it would be very difficult, if not impossible to regroup. It was his fanatical determination to remain operationally present and raise the stakes, it was his ambition for the group to join the elite of Greek revolutionary forces that kept RS going. And let's not forget that Roupa has a little boy to carry all by with herself.'12

Exactly a month after his arrest, Maziotis gave a newspaper interview headlined 'The only fight lost is the one that doesn't take place' where he repeatedly endorsed the claim that revolutionary militancy was and continues to be permanent and fundamental. 'Armed struggle, particularly in Greece', Maziotis argued, 'a country currently under vicious attack by the imperialistic capital and troika-imposed EU/ECB/IMF memorandums, is now more necessary than ever before'. ${ }^{13}$

The interview, as one would expect, was an exercise in self-justification and self-promotion. When asked why back in 2010 when arrested with Roupa and other four RS members, he accepted without any hesitation full political responsibility for the actions of the RS, Maziotis maintained that this was simply the duty of a genuine revolutionary. Sounding very similar to 17N's operational leader Dimitris Koufodinas (who willingly turned himself up in September 2002 to undertake the political responsibility of his group's actions), Maziotis said: 'As a fighter and as member of a wider armed revolutionary movement, I did the very obvious. I defended my organisation to which I belong to, I defended the attacks that were launched, and I defended the members of the group like Lambros Foundas who lost their lives fighting the regime'. ${ }^{14}$ 
The death of RS founding member Lambros Foundas ${ }^{15}$ during an exchange of fire with police in March 2010 must have been a major blow to Maziotis and Roupa at both personal and organisational level. Maziotis does not pause in the interview to communicate his emotional attachment to his fallen comrade but the fact that his son with Roupa was named after Foundas is indicative of the close relationship and deep bond between them.

Presenting himself and Roupa as champions of revolutionary purity and self-sacrifice, Maziotis stressed that 'at no point did we ever put ourselves first nor did ever try to save our own skins. Accepting political responsibility for us was a collective decision rather than a individual choice. Any other stance would have been a betrayal of our political principles and ideals and, most importantly, of our fallen comrades. ${ }^{, 16}$

It was clear from the interview, that Maziotis believed in his bones that military victory was achievable in Greece as long as organisations such as $17 \mathrm{~N}$ and RS existed. Although he did not mention $17 \mathrm{~N}$ by name it was evident from the language that he used throughout the interview that he regarded his group as the keepers of 17N's revolutionary flame. For Maziotis, RS ambition was always to surpass $17 \mathrm{~N}$ 's revolutionary experiment with a new revolutionary experiment becoming in the process the main catalyst for Greece's armed struggle movement. As he saw it, RS gave voice to a marginalised people disguising though the fact that his group when fully active possessed little inclination for organizing mass action. To illustrate his point Maziotis asked rhetorically: 'Why else, would the Greek state place two million euros on our heads if RS did not have any tangible impact on Greek society ${ }^{17}$

Maziotis offered a robust defence of the group's violent campaign by placing it in the political and historical context of the period. Their rejection of democratic methods and their readiness to exercise violence drew from the Greek experience with its deep historic 
traditions of ideologically motivated extremism. For Maziotis, the tradition of violence in Greece was unmistakable: 'There was history for us to follow', he said, and 'whoever does not understand this, has not understood anything about our struggle'. ${ }^{18}$

Surveying the course of the armed struggle both as a discourse and practice, Maziotis acknowledged that the first aim of any guerrilla group was primarily to survive, given the inevitable losses to be suffered at the hands of the state's counter-terrorism forces. 'In the fight for freedom and revolution,' Maziotis argued rather pragmatically, 'amidst a social and class war, there will be bloodshed, there will be deaths, there will prisons, there will be special anti-terrorism laws and special prison units for the members of the armed organizations'. 19 'The price', he added, 'that several members of European and Latin American militant organisations such as the Red Brigades, the Action Directe, the RAF and the Toupamaros have had to pay was death during operations, death from long prison sentences and hunger strikes'. ${ }^{20}$

Maziotis's perspective was clear: 'Provoking a response from the state is a given'. ${ }^{21}$ Lambasting, at the same time, those inside the Greek armed struggle movement he considered as weak comrades, Maziotis stated that it was 'nonsensical for anybody to expect that in the fight for freedom one would not be confronted with the might of the state and that the there won't be any heavy repercussions' ${ }^{22}$ Anybody, he sarcastically added, 'who considers himself to be a revolutionary fighter or an anarchist but operates within the parameters of legality they had better join a parliamentary party or join the system altogether rather than playing the revolutionary'. ${ }^{23}$

Reflecting upon the significance of his own arrest, Maziotis was equally forthcoming: As a member of RS, Maziotis said rather bombastically, he had always been conscious of the fact that the price of his 'choices was always going to be long imprisonment or death as a result of 
his confrontation with the dogs of the state'. ${ }^{24}$ At the same time, however, he added: 'The heavy cost and the repercussions for the revolutionary overthrown of the regime doesn't mean that we give up. Far from it.The only lost fight is the one that does not take place'. ${ }^{25}$

When asked, in the end of the interview, why he and Roupa violated their conditional release back in 2012 and went on the run, Maziotis's reply was unambiguous: 'That decision was taken mainly because we wanted to raise our child without him having to see us behind bars $^{26}$.

\section{The Consequences of A Failed Jailbreak}

'Under different circumstances, this text would have been written by both of us', wrote Pola Roupa in a bitter, angry communiqué that was posted on Athens Indymedia in March 2016, two months after her failed attempt to free her partner and comrade Nikos Maziotis from Korydallos prison by hijacking a helicopter. In the event, the attempted jailbreak failed as the helicopter never made it to the prison courtyard as planned after the pilot violently resisted forcing Roupa to abandon the operation.

Roupa was at pains to clarify that the decision to launch single-handedly an operation (which in the words of a Greek high-level counter-terrorism official was 'condemned to fail') was exclusively dictated by strategic rather than personal considerations. ${ }^{27}$ Unwilling to concede the obvious connection between the strategic and the personal, Roupa argued that 'organising to break out Nikos Maziotis was purely a political decision; as much as it was a political decision to liberate other political prisoners also, ${ }^{28}$. As far as Roupa was concerned this 'was not a personal choice'. 'If I wanted to only liberate my partner', she further argued rather unconvincingly, 'I would not have chartered a large helicopter, a fact that greatly complicated the organisational planning of the operation. The aim from the beginning was the liberation of other political prisoners who wanted together with us, to make their way to freedom' ${ }^{29}$ 
This operation, she asserted, 'in spite of its personal dimension, was not a personal decision but a political one. It was a step in the path to revolution. The same goes for my involvement in every past and future operation., ${ }^{30}$

Roupa made it clear that RS wanted to use this operation 'to cancel out the arrest of the comrade' but also as 'a way of an overall response to the state forces'. ${ }^{31}$ It should have come as no surprise to them, Roupa added somewhat patronisingly, that 'we were not going to leave Maziotis and the other comrades at the hands of the enemy without attempting to liberate them' ${ }^{32}$ For Roupa, it was imperative that if groups like RS were to maintain their political relevance they needed to able to militarily withstand and recover from setbacks' ${ }^{33}$ Looking back to the $2010 \mathrm{RS}$ arrests in order to illustrate her point, Roupa argued that 'we might have been apprehended by the state yet we were not defeated. We immediately took full political responsibility for our involvement in RS and worked hard to keep the organisation alive'. ${ }^{34}$

For Roupa defeat equalled to 'a rejection of your own self, of your own choices, of your dead comrades'. ${ }^{35}$ Defeat, she declared, 'never did and never will touch RS and me, personally. Because defeat and giving up is not befitting to revolutionaries. We have a duty to ourselves, to our comrades and society to keep the flame of belief for revolution alive, even when we are hit by the state repressive mechanisms'. ${ }^{36}$ For Roupa and the RS, 'it has always been strategically important to act whenever possible in cancelling out the state repressive mechanisms and the Korydallos jailbreak operation was part of that approach' ${ }^{37}$ Putting a brave face on the bungled operation, Roupa said in a defiant tone: 'this time, we didn't succeed but nothing is lost. In the struggle they will be successes as well as failures but the main thing is not to allow the failures to demoralise us' ${ }^{38}$ 
Refusing to evade uncomfortable truths, Roupa conceded that after Maziotis's arrest the stakes were high particularly because of the fact that 'the state and its repressive mechanisms have now concentrated all their hostility and focus on apprehending me although they should know by now how very difficult, if not impossible, this is' ${ }^{39}$ Roupa's bombastically articulated message to her pursuers was to the effect that in spite of the card that she was dealt with, she remained the master of her own fate.

One of the most interesting passages in Roupa's communiqué concerns her gender and and her representation by the mainstream media. Arguing that the media had contributed to an atmosphere of hysteria abandoning all pretence and dignity, Roupa said that she understood what drove the incessant moral hectoring. Although she never presented herself as an apostle for feminism, Roupa was particularly incisive in analysing the gendered framework of 'the incompatibility' between her roles as a woman, a militant and a mother. Roupa attacked the strictly defined gender roles and spaces, challenging at the same time the narrative that a woman who had chosen first to be an armed activist and then a mother constituted a transgression of the norms of female behaviour. 'I was more than certain', she said, 'that after this operation, irrespective of how it turned out, many would attempt to psycho analyse me because of the fact that I am not only a woman but also a mother. I'm not going to get involved into this conversation. I have always spoken politically. My personal life and everything around it doesn't concern anybody. The only thing I will say is that I have dedicated all my life fighting for social revolution. And I have taken many risks throughout my life for this fight. But then again, I'm stating the obvious: a revolutionary fight, a fight for social liberation without risks and blood doesn't exist'. ${ }^{40}$

Moving on to Greece's financial crisis and the pain and misery that years of austerity have inflicted on the people, Roupa held that half a decade of emergency bailouts had transformed the country into a de facto protectorate of its creditors. Roupa saw the urgent application of 
armed response as the only effective form of defence against the regime's submissiveness to the diktats of Brussels and its accomplices, namely the ECB and IMF. 'This time and age, more than any other period,' she said, 'it has become common knowledge in large segments of Greek society that the terrorists, the criminals and the thieves are those who govern. It is the economic and political elites who rob millions of ordinary people on a daily basis in the name of saving the system by allowing the troika impose memorandums and bail-out plans'. ${ }^{41}$

Roupa went on to argue, in a matter-of-fact tone, that 'what we now live in Greece is a war.' ${ }^{42} \mathrm{~A}$ class and social war, she added, which has 'claimed thousands of innocent victims up to now'. The essence of Roupa's position was that the country had no future and that the only thing to do was to resist the governments in siding with the financially powerful. 'And the only people putting resistance against them is a handful of revolutionaries which explains why the repressive apparatus of the state seek our political and physical destruction'. ${ }^{43}$

Roupa's communiqué ended with a warning and a threat. Roupa admitted, somewhat apologetically, that in order to finance the Maziotis break out operation but also 'survive in clandestinity' she had to expropriate a Bank [125,000 euros from the Piraeus Bank branch at the Athens Sotiria Hospital in June 2015]. ${ }^{44}$ In the fight for revolution, Roupa futher argued, 'the revolutionaries are at times obliged to seek the assistance of civilians. In such cases, we essentially ask them to take sides in a war. Once someone refuses to assist, they take a hostile position against the struggle. They effectively endanger or cancel undertakings, putting the lives of fighters in danger, and throwing obstacles in the way of a revolutionary process. They take, in other words, a clear position against a social and class war' ${ }^{45}$

The point Roupa, still smarting over the failed helicopter hijacking, tried to spell out was that she had to decided to re-evaluate her operational approach and she would be adopting a more 
nihilistic mindset in future operations. As she explained in detail: 'neither at Piraeus Bank nor during the helicopter operation did I make my identity known. Therefore, those involved were not aware that these were political actions. But after the failed escape attempt and given that I had the opportunity to kill the pilot but didn't, risking in the process my own life, I have to make the following public: from now on, whenever I need the assistance of civilians again, and if I deem it necessary, I will make my identity known from the start. And considering that my mission is about promoting the struggle for the overthrow of the criminal regime, everybody should know that any refusal of co-operation or any obstruction towards the execution of the operation will be dealt accordingly. Needless to add, that I have the personal details of the helicopter pilot but I would never threaten his family. I would never threat families or children'. ${ }^{46}$

\section{The Ulrike Menihof Syndrome}

'If you think that I will now break, you are very mistaken. I won't do you the favour of surrendering. Come and catch me, if you can'. This type of remark was made soon after Maziotis 2014 arrest in a raw 7,500 word communiqué-diatribe, and it was typical of Pola Roupa's thinking and conception of armed resistance. ${ }^{47}$

It was inconceivable to Roupa that an armed revolutionary would give up and surrender, however emotionally challenging his/her personal situation might have become because of the actions of the state. Roupa applied, in fact, the Dimitris Koufodinas definition of an armed revolutionary. A revolutionary, according to $17 \mathrm{~N}$ 's operational leader, is someone 'whose life choices are actually made against his or her personal interests. Someone who having to overcome his strong instincts for self-survival, he seeks a close encounter with a 
biologically unreasonable existence - unreasonable simply because he is in danger of losing his freedom'. ${ }^{48}$

The notion of Roupa, a woman on the run with child struck a nerve in the Greek extraparliamentary community making her a cause celebre, earning her at the same time sustained nationwide media coverage. Greece's best-selling newspaper Ta Nea ran a profile of Roupa, 'the only woman to have a one million euros put on her head' likening her impact on the country's armed struggle movement to that of Ulrike Meinhof of the West German guerrilla group Red Army Faction (RAF) ${ }^{49}$.

Meinhof had cofounded the group with Andreas Baader in 1970 after helping him to escape from a Berlin prison where he was serving for arson. Over its twenty-one-year history, the group evolved from a small militant gang (the Baader-Meinhof Gang as they were dubbed in the media in their early years) into a dangerous multi-levelled terrorist organisation that carried some of the most daring and spectacular operations in Europe. ${ }^{50}$ A charismatic personality who initially made her a name for herself as a political journalist and broadcaster Ulrike Meinhof went on to become the spokeswoman for the RAF's first generation of militants. ${ }^{51}$ From her cell, after her arrest in 1972, she was able to 'inspire a new generation of RAF members and ensure West German terrorism did not peter out' ${ }^{52}$

Was Pola Roupa a $21^{\text {st }}$-century Ulrike Meihof? Interestingly, Roupa's partner and comrade Nikos Maziotis posted in September 2014, a statement-tribute entitled Tribute to The RAF and Ulrike Meinhof to mark the 80 years since the birth of Ulrike Meinhof. ${ }^{53}$ It comes as little surprise that Maziotis is full of awe of Meinhof. In Maziotis's tribute, Meinhof belonged to a generation of West European revolutionaries for whom radicalism was part of their nature. Meinhof's RAF, Maziotis said, was not only the vanguard revolutionary left but also a 
major source of 'inspiration and reference for generations of rebels and certainly for several in my own generation' ${ }^{54}$

Assessing the RAF's impact by focusing on the group's evolution and Meninhof's revolutionary aspirations, Maziotis argued that 'Meinhof and the RAF had rightfully earned 'a place in the pantheon of the history of the revolutionary movement'. They have left, he added, 'an indelible mark in history; they are the benchmark for future generations of rebels and fighters. ${ }^{55}$

One of the core premises of Tribute to The RAF and Ulrike Meinhof was that armed revolutionary militancy was primarily a vocation of sacrifices. Revolutionaries such as Meinhof, Maziotis argued, 'had to make hard choices that led them to risk everything, to risk their lives and their freedom in the fight. ${ }^{56}$ Maziotis, perhaps out of humility does not mention RS, but one imagines that he includes Roupa and himself, when he discusses the emotional and psychological consequences of incarceration and human suffering that comes with revolutionary guerrilla warfare.

By his own admission, 'the road to human liberation from the chains of capital, imperialism and the state is not strewn with flowers, but paved with death, with blood, bullets, with violence, jail, isolation and everything that is generously offered by our enemy'. ${ }^{57}$ Meinhof, in Maziotis's opinion, was 'a heroine who sacrificed her own life for the greater revolutionary good'. She was 'a shining example that stood consistent until the end' ${ }^{58}$ However, the most remarkable passage in the tribute comes towards the end when Maziotis addresses the complex personal dilemmas and political realities Meinhof faced as an armed RAF activist and a woman. Maziotis, in fact, uses Meinhof as a case to make scathing observations on gender politics and more specifically on gender as a relation of power. Ridiculing simplistic assumptions about the involvement of women in armed resistance due 
to love and romance, Maziotis confronts long-established societal constraints and restrictive gender norms and stereotypes where women remain invisible and ignored. In Maziotis's mind, the main reason why Meinhof became a cult figure among European female militants was because of the fact that although she belonged to a gender-conservative age, she proved that women could be valued and valuable strategic actors. The story of what Ulrike Meinhof achievements does not need re-telling here, Maziotis said full of admiration, but her determination to go against the tide and 'break the established roles of sexist society that wanted women to be subordinate or submissive underdogs to men', makes her an icon. ${ }^{59}$ Nobody did more, Maziotis argued, over the past fourty years than Meinhof to 'impose the notion of women as worthy and equal fighters who fought with a gun in hand' ${ }^{60}$

With poetic optimism the tribute concluded: 'We, in Revolutionary Struggle believe that the best homage to comrades who gave their lives in the struggle is the continuation of the same struggle in which they fell fighting. Today, more than 40 years after the founding of the RAF and in completely different conditions; in the conditions of the global capitalist crisis -the longest in the history of capitalism so far- the absence of armed action in the cities of the developed capitalist territory of Europe and the USA is more apparent than ever. Today's struggle must be led by the example of all those who in earlier times gave their lives or endured and remained unrepentant. Honor to Ulrike Meinhof; Honor to the dead of social and class warfare; Honour to the unrepentant ${ }^{61}$

Although she is not mentioned by name in the Tribute to The RAF and Ulrike Meinhof the text's ultimate purpose is to vindicate Roupa who Maziotis clearly sees as a $21^{\text {st }}$-century version of Ulrike Meinhof. Throughout the text there is an implied comparison between Meinhof's and Roupa's personal and revolutionary trajectories. Fixated on the memory of Meinhof, the RS leaders saw their violence as a historical extension of the RAF's 
revolutionary grand narrative within a Greek context. Following Meinhof's example, Roupa wanted - to use the words of Nobel prize-winning author and playwright Elfriede Jelinek - to become 'the central figure around which questions of violence and the support of the underground struggle were polarised'. ${ }^{62}$ Roupa, like Meinhof, wanted to 'move people politically' by creating an insurrectionary mood that would awaken consciences and radicalize people. In their own minds, Meinhof and Roupa were fighters for revolutionary justice which explains why they ferociously rejected the designation of them as terrorists and of their actions as terrorism.

It is a measure of Roupa's total commitment to the revolutionary cause that the birth of her own son while in prison failed to make her reassess her previous life choices. The arrival of little Lambros (named after dead RS commando Lambros Foundas) changed nothing for his parents. In fact, his arrival radicalised them further. As Maziotis put it in 2011 while on hunger-strike after the prison authorities refused him visiting rights to the maternity hospital: 'all our struggles take place so that we can hand over to our children a better world while making certain that we never place ourselves in the difficult position of having at some point to admit to them when they grow up that we did nothing to resist the unfairness of the existing system' ${ }^{63}$

Roupa sought to morally capitalise on her dual role as militant and mother, seeking to garner sympathy for 'the abuse and humiliation' she endured at the hands of her jailors during her pregnancy and after giving birth. ${ }^{64}$ Roupa's most zealous attacks, when on the run from the police, were directed at an 'openly violent and vindictive state' which used 'terroristic interrogation methods' against her wider family [her mother and sister] in order to apply pressure on her to surrender. ${ }^{65}$ 'My persecutors', she said, 'know me well enough by now to know that is not going to happen'. ${ }^{66}$ 
How will history judge the RS? The RS, after the failed helicopter jailbreak operation and Roupa's subsequent capture, have come full circle. Roupa and Maziotis preoccupied with their reputation and legacy continue, from their prison cells through texts, declarations, interventions, to edit posterity's vision of them by offering a defence of their actions. Maziotis and Roupa have somewhat predictably refused to admit defeat and to accept that they have come to the end of the line but at the time of writing neither hardcore elements within the RS commando/resistance levels have emerged to resume the campaign nor any other organisation has emerged to pick up the baton of violence from RS.

History will judge RS as a failed group that never managed to evolve into an 'armed people's revolutionary movement' as was the stated ambition in their 2004 manifesto. Like $17 \mathrm{~N}$, the group they aspired to succeed, the RS never created a situation of crisis for the Greek political and economic establishment. Maziotis and Roupa saw themselves as the crème de la crème of the post-17N Greek armed struggle movement but in the end RS could not find its way out of the large shadow cast by $17 \mathrm{~N}$ 's mythological status. If there is, however, one thing that RS shared with $17 \mathrm{~N}$ was that both groups in their obsessive attempt to affect political reality they blithely ignored the Clausewitzian axiom that violence 'should not take the place of the political purpose, nor obliterate it' ${ }^{67}$

\footnotetext{
${ }^{1}$ Until the group's demise in 2002, Greece had suffered one of the most lethal, protracted and intransigent ideological campaigns of terrorism in Europe. $17 \mathrm{~N}$ commandos assassinated foreign diplomats as well as Greek politicians, magistrates, newspaper publishers, industrialists and shipowners, planting roadside bombs and firing rockets against foreign embassies and businesses. Astonishingly, in all that time not one $17 \mathrm{~N}$ operative was killed or injured; neither in an operation nor as a result of actions by the Greek security and intelligence agencies. For a group profile see George Kassimeris, Europe's Last Red Terrorists: The Revolutionary Organization 17 November (New York: New York University Press, 2001).

${ }^{2}$ The CCF, a looser, horizontal structure of individual cells, gained global fame in November 2010 when it forced the Greek government to take the unprecedented step of suspending international airmail for 48 hours in order to put a stop to a wave of CCF mail bombs. Mail bombs were sent to German Chancellor Angela Merkel, Italian Premier Silvio Berlusconi, and French President Nicolas Sarkozy, as well as to a number of foreign embassies in Greece and across Europe, causing a major international security scare. For a full
} 
organisational profile of CCF see George Kassimeris, Inside Greek Terrorism (New York: Oxford University Press, 2013), pp.95-113.

${ }^{3}$ For membership profiles and personal histories of the new generation of Greek militants, see Kassimeris, Inside Greek Terrorism

${ }^{4}$ See Roupa profile in the Greek newspaper Ta Nea entitled 'Pola Roupa: The Ulrike Meinhof syndrome', 13 August 2014.

${ }^{5}$ Athens Court Archive, dated March 1999.

${ }^{6}$ Ibid.

${ }^{7}$ lbid.

${ }^{8}$ Ibid.

${ }^{9}$ RS attack communiqué, dated 12 March 2009.

${ }^{10}$ Maziotis and Roupa were convicted in April 2013 in absentia; each was sentenced to 50 years for leading a terrorist organisation.

${ }^{11}$ Telephone conversation with the author, July 2014.

${ }^{12}$ Author interview, Athens, June 2015.

${ }^{13}$ Maziotis newspaper interview to mark to one year of his arrest. Efimerida ton Syntakton, 15 July 2014. ${ }^{14}$ Ibid.

${ }^{15}$ 35-year-old Foundas was shot dead in exchange of fire with the police during an RS operation to steal a car in the early hours of the morning on 11 March 2010. Foundas's accomplice, believed by the Greek counterterrorism to be Maziotis, managed to escape. Next to the body of the fatally wounded RS commando, police found a walkie-talkie and a backpack with a handmade bomb of a similar type used in previous RS operations. ${ }^{16}$ Maziotis interview, Efimerida ton Syntakton, 15 July 2014.

${ }^{17}$ Ibid.

18 Ibid.

${ }^{19} \mathrm{Ibid}$

${ }^{20}$ Ibid.

${ }^{21}$ Ibid.

22 Ibid.

${ }^{23}$ Ibid.

${ }^{24} \mathrm{lbid}$

${ }^{25} \mathrm{Ibid}$.

${ }^{26}$ Ibid.

${ }^{27}$ Author interview, Athens, June 2016.

${ }^{28}$ Pola Roupa communiqué regarding the Maziotis failed jailbreak form Korydallos prison, dated March 2016.

${ }^{29}$ Ibid.

${ }^{30}$ Ibid.

${ }^{31} \mathrm{lbid}$

${ }^{32}$ Ibid.

${ }^{33} \mathrm{Ibid}$

${ }^{34}$ Ibid.

${ }^{35}$ Ibid.

${ }^{36}$ Ibid.

${ }^{37}$ Ibid.

${ }^{38} \mathrm{Ibid}$

${ }^{39}$ Ibid.

${ }^{40} \mathrm{lbid}$

${ }^{41}$ Ibid.

${ }^{42}$ Ibid.

${ }^{43}$ Ibid.

${ }^{44}$ Ibid.

45 lbid.

${ }^{46} \mathrm{Ibid}$

${ }^{47}$ Roupa's 'Come and catch me, if you can' communiqué, dated August 2014.

${ }^{48}$ Dimitris Koufodinas, Court proceedings, Korydallos prison chambers, 24 July 2003. 
${ }^{49}$ Inspired by Che Guevara's 'focus theory' the RAF leadership believed that the preconditions for a revolution can be created by an armed avant-garde which then were to provoke the German state terrorism into a vicious, disproportionate response that would lead the German people to revolt.

${ }^{50}$ Dennis Pluchinsky, veteran State Department terrorism analyst, offers a brilliant organizational and operational profile of the RAF in Y. Alexander and D. Pluchinsky (eds) European Terrorism: Today \& Tomorrow (McLean, VA: Brassey's, 1992). pp.43-92.

51 'Before going underground, Meinhof had a high-profile career as a journalist and broadcaster writing for newspapers and magazines and making current affairs programmes for radio and television. In her biweekly columns for konkret, an influential magazine for the political left magazine (which she also edited) Meinhof wrote about world politics, the developing world, social justice and gender politics.

${ }^{52}$ As Leith Passmore writes in his book Ulrike Meinhof and the Red Army Faction Meinhof spent, in fact, more time in prison than on the run and the 'texts she produced as an inmate would be come at least as important as anything she produced while at large' Inside prison, writes Passmore, 'Meinhof managed to reinvent RAF rhetoric for a prison context and subsequently for a trial audience. Her voice also echoed long after her death, as she prepared the discursive foundation for the RAF violence of the 1980s and 1990s, as well as much of the RAF myth of the twenty-first century. See Ulrike Meinhof and the Red Army Faction: Performing Terrorism (Basingstoke: Palgrave, 2011).

${ }^{53}$ Tribute to The RAF and Ulrike Meinhof, dated September 2014.

${ }^{54}$ Ibid.

${ }^{55}$ Ibid.

${ }^{56} \mathrm{Ibid}$.

${ }^{57}$ Ibid.

${ }^{58} \mathrm{Ibid}$.

${ }^{59} \mathrm{Ibid}$.

${ }^{60} \mathrm{Ibid}$.

${ }^{61} \mathrm{lbid}$

${ }^{62}$ See Elfriede Jelinek's reflection on Meinhof in Karin Bauer (ed.), Everybody Talks About The Weather: We Don't (New York: Seven Stories, 2008), pp.8-11. See also Sarah Colvin, Ulrike Meinhof and West German Terrorism: Language, Violence, and Identity (Columbia, SC: Camden House, 2009).

${ }^{63}$ Maziotis interview in To Vima newspaper, 16 October 2011.

${ }^{64}$ Pola Roupa communiqué, dated March 2016.

${ }^{65}$ Ibid.

${ }^{66}$ Ibid.

${ }^{67}$ See Peter Paret, 'Clausewitz', in P.Paret (ed.), Makers of Modern Strategy (Oxford: Oxford University Press, 1986), p.200. 